\title{
Efficacy of Zinc Sulphate and Amifostine in Prevention of Radiation Induced Salivary Gland Damage
}

\section{Radyasyona Bağlı Tükürük Bezi Hasarının Önlenmesinde Çinko Sülfat ve Amifostin Etkisi}

Meryem Aktan ${ }^{1}$

Mustafa Vecdi Ertekin²,

Ebru Orsal ${ }^{3}$,

Hilal Kiziltunc Ozmen ${ }^{4}$

${ }^{1}$ Department of Radiation Oncology, Meram Faculty of Medicine, Necmettin Erbakan University, Konya, Turkey

${ }^{2}$ Department of Radiation Oncology, Faculty of Medicine, Nisantasi University, Istanbul, Turkey

${ }^{3}$ Department of Nuclear Medicine, Faculty of Medicine, Ataturk University, Erzurum, Turkey

${ }^{4}$ Department of Radiation Oncology, Faculty of Medicine, Ataturk University, Erzurum, Turkey

Geliş Tarihi/Received: 15 December 2017 Kabul Tarihi/Accepted: 05 May 2018

\begin{abstract}
Öz
Amaç: Baş ve boyun kanserlerinin tedavisinde radyoterapi önemli rol oynar. Bununla birlikte, küratif tedavide mukozit ve ağız kuruluğu en sık görülen yan etkilerdir. Bu prospektif, randomize çalışmanın amacı, baş ve boyun kanserli hastalarda radyasyon kaynaklı tükürük bezi hasarının önlenmesinde çinko sülfat ve amifostinin etkinliğini kantitatif tükürük bezi sintigrafisi (QSGS) kullanarak karşılaştırmaktır.

Hastalar ve Yöntem: Radyo \pm kemoterapi alan 30 baş-boyun kanseri hastası çinko sülfat veya amifostin gruplarına random olarak atandı. Tüm hastalar RT sırasında haftada bir kez Radyasyon Tedavisi Onkoloji Grubu (RTOG) Akut Radyasyon Morbidite Skorlaması kullanılarak oral mukozit yönüyle değerlendirildi ve kilo takibi yapıldı. Tedaviden önce ve 2 ay sonra tükürük bezi sintigrafisi çekildi. Zaman-aktivite eğrilerini kullanılarak, tedavi öncesi ve sonrası arasındaki maksimum alım (UR) ve bağıl tükürük atılımı oranındaki (ER) değişiklikler hesaplandı. Ölçümler istatistiksel olarak Mann-Whitney U testi kullanılarak karşılaştırıldı. Istatistiksel anlamlılık $\mathrm{p}<0.05$ olarak tanımlandı.

Bulgular: Çinko sülfatın tükürük bezleri üzerindeki koruyucu etkisi amifostine benzerdi ve UR, ER sonuçları, oral mukozit veya iki grup arasında kilo kaybı arasında istatistiksel olarak anlamlı bir fark yoktu. Sonuç: Her iki destek tedavisinin etkinliği karşılaştırıldı ve istatistiksel olarak anlamlı bir fark bulunamadı. Bununla birlikte, maliyet farkı nedeniyle, çinko sülfat kullanımı, ağız kuruluğu, oral mukozit ve diğer toksik etkilerin önlenmesi için amifostine bir alternatif olabilir. Bu konuda daha fazla hasta ile daha uzun takip süreleri içeren çalışmaların yapılması önerilmektedir.
\end{abstract}

Anahtar Kelimeler: Amifostin, baş-boyun kanseri, radyasyon, çinko sülfat

\section{Abstract}

Aim: Radiotherapy plays a significant role in the management of head and neck cancers. However mucositis and xerostomia are the most common side effects in curative treatment. The aim of this prospective, randomized study is to compare the efficacy of zinc sulphate and amifostine in preventation of radiation induced salivary gland damage in head and neck cancer (HNC) patients using quantitative salivary gland scintigraphy (QSGS)

Patients and Methods: Thirty patients with HNC who had received radio \pm chemotherapy were randomly assigned to receive either zinc sulfate or amifostine. All the patients were once a week during RT for oral mucositis using the Radiation Therapy Oncology Group (RTOG) Acute Radiation Morbidity Scoring criteria, and measurement of body weight. Before and 2 months after treatment, salivary gland scintigraphy was performed. Using the time-activity curves, changes in the maximum uptake (UR) and relative saliva excretion rate (ER) between pre- and post- treatment were calculated. The measurements were statistically compared using paired Mann-Whitney U test. Statistical significance was defined as $p<0.05$.

Results: The protective effect of zinc sulphate on the salivary glands was similar to amifostine and there were no statistically significant difference in UR, ER results at QSGS, oral mucositis or weight loss between the two groups.

Conclusion: The effectiveness of both support therapy was compared and there was no significant difference in efficacy. However, because of the cost difference, the use of the zinc sulphate can be an alternative to amifostine for prevention of xerostomia, oral mucositis and other toxic effects. Further studies with more patients and follow-up are suggested in this regard.

Keywords: Amifostine, head-and-neck cancer, radiation, zinc sulphate

\section{INTRODUCTION}

Radiotherapy (RT) plays a significant role in the management of head and neck cancers (HNC), either for definitive or post-operative adjuvant RT (1). However a better treatment outcome, side effects related to treatment is one of the major goals in cancer treatment (2). The most common radiaton- induced side effects in curative treatment of HNC are mucositis and xerostomia (3). Mucositis is an acute toxicity that occurs during the treatment; xerostomia usually develops during chemoradiotherapy and persists for a long period (4). These may result in severe complications and various symptoms such as sticky saliva, dental decay, alterations of the taste,

Address correspondence to: Meryem Aktan, Necmetin Erbakan University, Meram Faculty of Medicine Department of Radiation Oncology, 42090 Konya, Turkey 
difficulties in mastication, loss of quality of life and socioeconomic costs $(2,5)$.

The most common used radioprotective agent is amifostine, which is a hunter of free radicals produced by ionizing radiation and protect normal cells, but not tumor cells. The combine use of amifostine with conventional RT significantly reduce rate of xerostomia (3).

Zinc is an essential micronutrient for the human body. A major biochemical function of zinc is the maintenance of membran structure, regulation of immun function and the role of metalloenzyme activities. And also has direct and selective effect on cancer cells and indicate the apoptosis $(6,7)$. Zinc deficiency is commonly presented in a large percentage of HNC (8). In nonmalignant diseases zinc supplementation is widely known to improve the immunity (9). However, in irradiated HNC patients, the effect of zinc supplementation on cell mediated immunity and clinical benefits are not clear. Several studies related with the benefits of zinc supplementation in cancer patients mostly focus on relieving the radiation-induced mucositis and improving the quality of life (10-12).

The aim of this prospective, randomized study is to compare the efficacy of zinc sulphate and amifostine in preventation of radiation induced salivary gland damage in HNC patients using quantitative salivary gland scintigraphy (QSGC).

\section{PATIENTS AND MATERIALS Study Design}

This was a prospective, randomized controlled study design in which patients were randomly assigned to receive either amifostine or zinc sulphate as a radioprotective agent during RT. The design of the present study was approved by the local ethics committees (Ataturk University, Faculty of Medicine 2008/24), where the study was conducted and all patients signed an informed consent.

\section{Patients' characteristics}

Thirty patients with HNC who had received RT or chemoradiotherapy were randomly assigned to receive either zinc sulfate (Zinco-220 $50 \mathrm{mg}$ capsule, Berko ${ }^{\circledR} \mathrm{n}=15,57 \%$ ) or amifostine (Ethyol 500 mg flacone, Erkim $\circledast, n=11,43 \%) .4$ patients were excluded; 2 patients were died during treatment, 2 patients left the study. Patient $>15$ years old and Karnofsky's performance status $\geq 70$ were eligible for the study. Table 1 provides patients characteristics of two study groups.

\section{Radiotherapy}

The patients were treated with conformal RT technic using multileaf collimator lineer accelerator (LINAC MLC, Siemens) with photons and electrons of different energies, the dose per fraction was 1.8- 2 Gy with five fractions per week. İmmobilization had provided with a thermoplastic mask for all patients. In all cases, parotid and submandibular glands were directly adjacent to the target volume and could not be spared. Anterior and lateral wedged fields, lateral opposing fields or other similar field arrangements were used for treatment of the tumor and the adjacent lymph nodes levels. For planning and treating of the boost volume, computed tomography-based, 3-D treatment planning method was used. The median RT

Table 1. Patient characteristics

\begin{tabular}{lll}
\hline Variable & Amifostine group & Zinc sulphate group \\
\hline Gender (n) & 9 & 9 \\
$\quad$ Male & 2 & 6 \\
$\quad$ Female & $28-75$ & $17-71$ \\
Age & 54 & 46 \\
$\quad$ Range & 5 & 5 \\
$\quad$ Median & 2 & 4 \\
Tumor site (n) & - & 2 \\
$\quad$ Nasopharynx & 2 & 2 \\
$\quad$ Larynx & 2 & 2 \\
$\quad$ Lip & 10 & 12 \\
$\quad$ Thyroid & 1 & 3 \\
$\quad$ Oral cavity-oropharynx & & \\
Concurrent chemoradiotherapy (n) & & $54-72$ \\
$\quad$ Yes & $56-70$ & 67 \\
$\quad$ No & 67 & \\
Radiotherapy dose (Gy) & & \\
$\quad$ Range & &
\end{tabular}


dose was 67 Gy (range 56-70 Gy) in amifostine group and 67 Gy (range 54-72 Gy) in zinc sulfate group.

\section{Drug Therapy}

Zinc sulfate (containing $50 \mathrm{mg}$ zinc, Zinco-220 capsule, Berko®) and amifostine (Ethyol $500 \mathrm{mg} 1$ flacone, Erkim ${ }^{\circledR}$ ) were administered randomly to the patients in the study. In zinc sulphate group, zinc capsules were given three times daily during RT. In amifostine group, amifostine was given $200 \mathrm{mg} /$ $\mathrm{m} 2$ dose subcutaneously, 15 minutes before RT, simultaneously during RT. In addition, analgesic, antifungal and antibacterial agents were given if necessary.

12 patients in zinc sulphate group and 10 patients in amifostine group were given concomitant platin based chemotherapy at $40 \mathrm{mg} / \mathrm{m} 2$ dose weekly.

\section{Quantitative salivary gland scintigraphy}

Before and 2 months after RT, QSGC was performed from all patients in the department of nuclear medicine with a gamma camera (GE-Starcade 4000 XR / T, St Albans, Hertfordshire, UK) equipped with a low energy parallel-hole, high resolution collimator. Energy level was $140 \mathrm{keV}$ and the window range was $20 \%$. Salivary gland scintigraphy was performed after a 4 hours fasting. In supine position, technetium-99m pertechnetate about $5 \mathrm{mCi}(185 \mathrm{MBq})$ was injected intravenously in to antecubital vein. Dynamic images were taken after the technetium injection and then activity measurements were taken at 1st, 20th and 40th minutes on these images. 20 minutes after the injection, $5 \mathrm{~mL}$ diluted lemon juice administered to dorsal tongue to stimulate the salivary flow.

Time-activity curves were calculated using

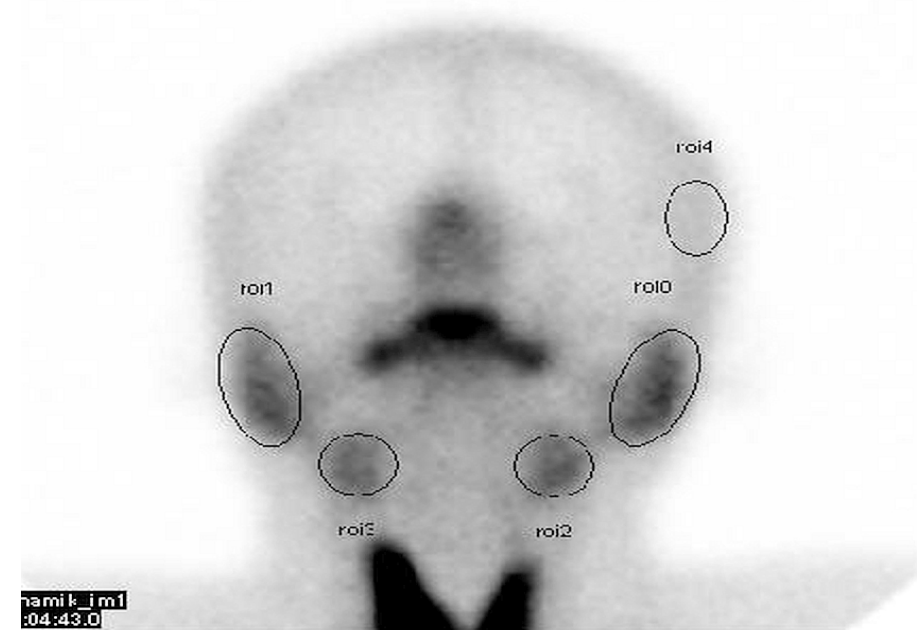

Figure 1. Regions-of-interest manually drawn oval regions-of-interest around both the parotid and submandibular glands. For background correction, a fifth region-of-interest of similar size was drawn over the cerebrum (Figure 1). Using the time-activity curves for pre-treatment and post-treatment time, the parameters Upremax, Upostmax (maximum uptake pre-treatment and posttreatment) and Upremin, U post min (minimum uptake after stimulation pre-treatment and post-treatment) were determined separately for each gland and then two parameters were calculated;

1. Change in the maximum uptake (UR) between preand post- treatment:

$$
\Delta U=\frac{U^{\text {post }} \max -U^{\text {premax }} \max }{U^{\text {premax }}}
$$

2. Change in the relative saliva excretion rate (ER) between pre- and post- treatment:

$$
\Delta \mathrm{E}=\frac{\Delta \mathrm{E}^{\text {post }}-\Delta \mathrm{E}^{\text {pre }}}{\mathrm{E}^{\text {pre }}}
$$

\section{Follow- up}

All the patients were examined by two independent radiation oncologist once a week during $\mathrm{RT}$ for oral mucositis using the Radiation Therapy Oncology Group (RTOG) Acute Radiation Morbidity Scoring criteria, and measurement of body weight. Data collected from all patients were recorded every week. Patients were examined 6 weeks after completing RT and then 3 month intervals within the first year. Posttherapeutic salivary gland scintigraphy was performed 2 months after RT.

\section{Statistical analysis}

After the necessary data had been collected, statistical analyses were performed with SPSS version 15.0 (SPSS Inc., Chicago, IL, USA). The data corresponded to mean \pm standard deviation (SD) was calculated for both salivary flow rates and mean URs, and also oral mucositis and weight loss between amifostine and zinc sulphate group. The measurements were statistically compared (UR and ER \%) with salivary flow rate using the paired MannWhitney $U$ test. Statistical significance was defined as $p<0.05$.

\section{RESULTS}

Between two groups, patients and treatment characteristics were balanced. An imbalance of the tumor site distribution was due to that 2 patients were died during treatment and 2 patients left the study in amifostine group. All patients tolerated the treatment concepts. Only 1 patient in amifostine group, skin 


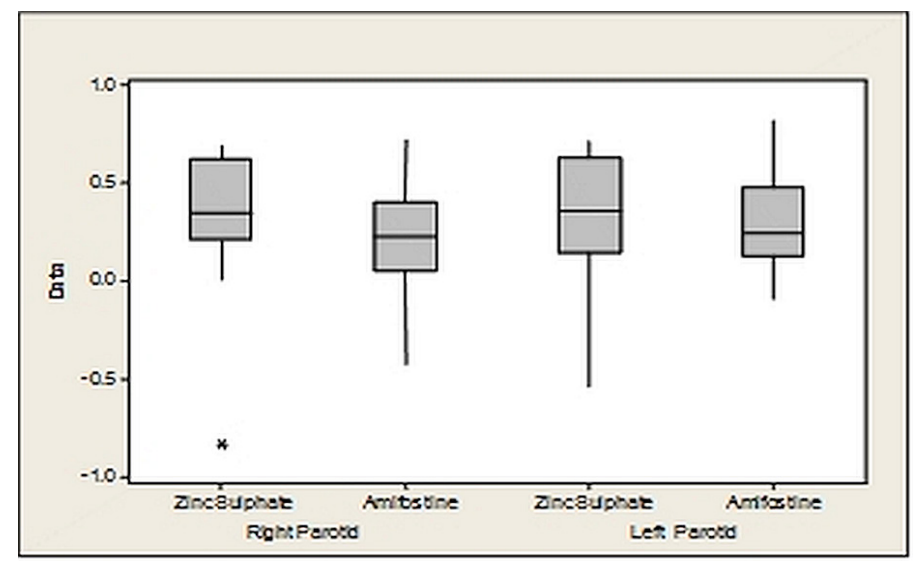

Figure 2. Change in maximal uptake $(\Delta U)$ for parotid glands

reaction was seen at 9th day of treatment, stopped the using of amifostine, had given zinc sulfate and included to zinc sulphate group. For the remaining patients, therapy could be completed as planned.

Altogether 52 salivary gland scintigraphies of 26 patients were analyzed for comparison of two treatment groups. The parameters of parotid and submandibular gland functions ( $\Delta \mathrm{U}$ and $\Delta \mathrm{E})$ were calculated using formulas.

The result of the current study, which was carried out in amifostine and zinc sulphate groups shows the flow rate analysis between the groups before and after RT. The result infers a reduction in the salivary flow rate in post-RT patients, when compared with the pre-RT patients in both of amifostine and zinc sulphate group.

The scintigraphic UR and ER in amifostine and zinc sulphate groups were compared, the values in these two categories showed a decrease in both UR and ER in two groups and there was no statistically significant difference between two groups (Table 2 and Figure 2-3).

All the patients were examined once a week during

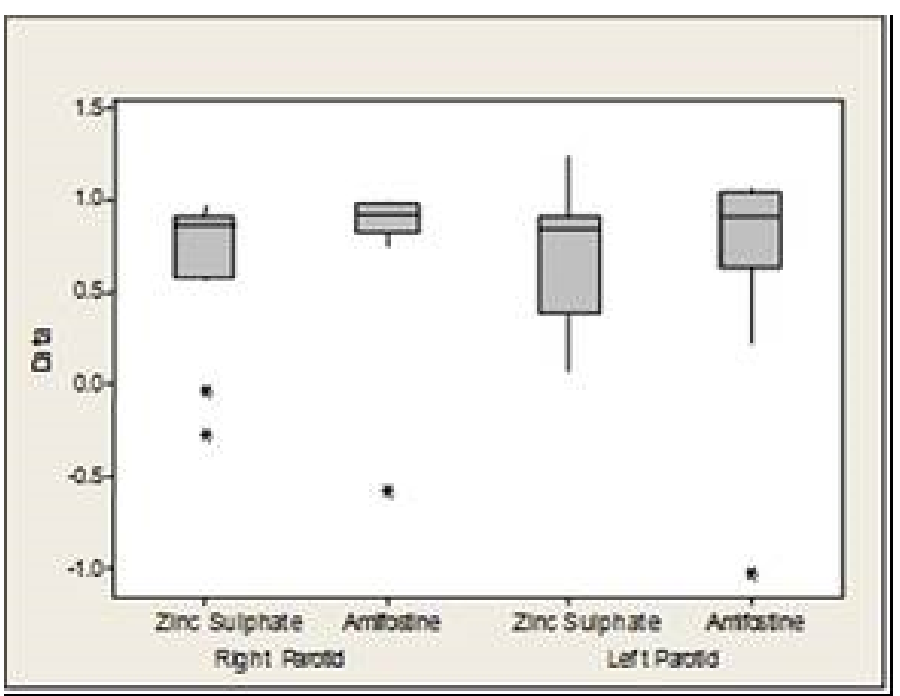

Figure 3. Change in relative excretion rate $(\Delta \mathrm{E})$ for parotid glands

RT for oral mucositis using the RTOG Acute Radiation Morbidity Scoring criteria. In amifostine group, oral mucositis was seen at 12 th day (10th-15th day) and in zinc group at 13th day (10th-18th days). In amifostine group, grade 1 mucositis was observed in a patient (3.8\%), grade 2 in 5 patients (19.2\%), grade 3 in 3 patients $(11.5 \%)$ and grade 4 in 2 patients $(7.6 \%)$. In zinc group, grade 1 mucositis was observed in 2 patients (7.6\%), grade 2 in 10 patients (38.4\%) and grade 3 in 3 patients (11.5\%). Grade 4 mucositis was not observed in any patients. There was no statistically significance difference between two groups according to RTOG oral mucositis criteria $(p=0.16)$. The median weight loss was $7.18 \mathrm{~kg}(2-12 \mathrm{~kg})$ in amifostine group and $7.53 \mathrm{~kg}(2-14 \mathrm{~kg})$ in zinc sulphate group during the RT and it was not statistically significant $(p=0.81)$

\section{DISCUSSION}

About half a million cases of HNC are diagnosed

Table 2. $\Delta \mathrm{U}$ and $\Delta \mathrm{E}$ values of salivary glands between two groups

\begin{tabular}{|c|c|c|c|c|}
\hline Parameters & Salivary Glands & $\begin{array}{l}\text { Zinc sulphate Group } \\
(n=15) \text { Mean } \pm \text { SD }\end{array}$ & $\begin{array}{l}\text { Amifostine Group } \\
(n=11) \text { Mean } \pm \text { SD }\end{array}$ & P value \\
\hline \multirow[t]{4}{*}{$\overline{\Delta \mathrm{U}}$} & Right parotid & $0.30 \pm 0.17$ & $0.21 \pm 0.09$ & 0.35 \\
\hline & Left parotid & $0.31 \pm 0.13$ & $0.27 \pm 0.06$ & 0.57 \\
\hline & Right submandibular & $-0.08 \pm 1.03$ & $-0.07 \pm 1.16$ & 0.21 \\
\hline & Left submandibular & $-0.05 \pm 1.24$ & $-0.01 \pm 1.14$ & 0.30 \\
\hline \multirow[t]{4}{*}{$\Delta \mathrm{E}$} & Right parotid & $0.67 \pm 0.16$ & $0.76 \pm 0.22$ & 0.19 \\
\hline & Left parotid & $0.73 \pm 0.12$ & $0.60 \pm 0.39$ & 0.29 \\
\hline & Right submandibular & $0.35 \pm 0.51$ & $0.66 \pm 0.33$ & 0.22 \\
\hline & Left submandibular & $0.50 \pm 0.63$ & $0.67 \pm 0.32$ & 0.64 \\
\hline
\end{tabular}


yearly around the world (13). RT or radiochemotherapy is the most common treatment strategy especially locally advanced diseases. However, the treatment of these patients is complicated by critical organs, especially salivary glands in this area (4).

Different approaches have been established to prevent xerostomia and related side effects and protect the salivary glands after RT. One approach is the use of pharmacological agents, such as amifostine, which has been shown to reduce the clinical and histological manifestation of radiation related xerostomia (14).

Amifostine is widely used as a radioprotector agent to reduce xerostomia and mucositis in the treatment of HNC. Brizel et al. (3) observed that the incidence of grade 2 or higher xerostomia is significantly reduced from $78 \%$ to $51 \%$ with using amifostine compared with the control group. In the meta-analysis, Gu et al. (4) demonstrated that use of amifostine significantly reduced the radiation-induced toxicities of serious mucositis, acute or late xerostomia and dysphagia.

Zinc is an essential micronutrient in the human body and has an important role on cell membrane structure. Zinc has apoptosis-inhibiting effect in normal cells; however it induces apoptosis with a selective effect on cancer cells $(7,15)$. And also zinc has antioxidant, anti-apoptotic, anti-inflammatory roles and an important co-factor at DNA synthesis (16).

Prasad et al have reported low serum zinc levels in $53 \%$ of HNC patients (17). In other study RostkowskaNadolska et.al were found low serum zinc levels in all 78 larynx cancer patient's serum before treatment (18).

Zinc sulfate is reported to be beneficial in decreasing the severity of radiation-induced oral discomfort, mucositis and dermatitis in patients with $\operatorname{HNC}(10,19)$.

Tanaka was observed the relationship between xerostomia, zinc deficiency and taste disorders. They measured serum zinc levels in 93 patients with xerostomia and/or hypogeusia compared with 60 control patients and salivary gland function with salivary gland scintigraphy. They observed low salivary gland secretion values in patients with zinc deficiency (20). In other study, Watanabe et al. (11) was used polaprezinc (zinc L-carnosine) to investigate the effect on radiochemotherapy-induced xerostomia, oral mucositis, taste disturbance and pain in $16 \mathrm{HNC}$ patients and 15 controls.

According to the results obtained from research in cancer therapy, zinc sulphate can be used as radioprotectors to reduce the radiation-induced mucositis or xerostomia in HNC patients. Amifostine is also used in prevention of xerostomia and can be used to prevent oral mucositis. Based on these evidences, we compared the impacts of amifostine and zinc sulphate on preventing side effects of RT.

Salivary gland scintigraphy produces objective, dynamic and quantitative measurement of the major salivary gland function while measuring the total saliva production, and it allows for differentiation of abnormalities in saliva production as uptake ratios (UR) and secretion as excretory ratios $(E R)(2,21)$. To our knowledge, this is the first trial comparing directly the effect of amifostine and zinc sulphate in reducing xerostomia using functional parameters of QSGS. We used QSGS and clinical examinations to evaluate xerostomia, oral mucositis and weight loss, and there were no statistically significant differences between the two groups.

There are some limitations to our study. The sample size of our study was relatively small. The other limitation is that, follow-up was not long enough to show long-term effects and safety of zinc sulphate and amifostine therapy.

\section{CONCLUSION}

The protective effect of zinc sulphate on the salivary glands was similar to amifostine and there was no statistically significant difference in UR and EF results at QSGS between the two groups. In addition, the effects of amifostine and zinc on oral mucositis were similar to the literature.

The effectiveness of the both support therapy was compared and there was no significant difference in efficacy. However, because of the cost difference, the use of the zinc sulphate can be an alternative to amifostine for the prevention of xerostomia, oral mucositis and other toxic effects due to RT based on these results, further studies with more patients and control groups and with longer follow-ups are suggested in this regard.

Conflict of interest: Authors declare that there is no conflict of interest between the authors of the article.

Financial conflict of interest: Authors declare that they did not receive any financial support in this study.

Address correspondence to: Meryem AKTAN, Necmetin Erbakan University, Meram Faculty of Medicine Department of Radiation Oncology, 42090 Konya, Turkey e-mail: meryemaktan@gmail.com

Tel: + 903322237263 Fax: + 903322236181 


\section{REFERENCES}

1. Toledano I, Graff P, Serre A, et al. Intensity modulated radiotherapy in head and neck cancer: Results of the prospective study GORTEC 2004-03. Radiother Oncol 2012;103(1): 57-62.

2. Münter MW, Hoffner $\mathrm{S}$, Hof $\mathrm{H}$, et al. Changes in salivary gland function after radiotherapy of head and neck tumors measured by quantitative pertechnetate scintigraphy: Comparison of intensity-modulated radiotherapy and conventional radiation therapy with and without Amifostine. Int J Radiat Oncol Biol Phys 2007;67(3):651-9.

3. Brizel DM, Wasserman TH, Henke M, et al. Phase III randomized trial of amifostine as a radioprotector in head and neck cancer. J Clin Oncol 2000;18(19):3339-45.

4. Gu J, Zhu S, Li X, et al. Effect of amifostine in head and neck cancer patients treated with radiotherapy: A systematic review and meta-analysis based on randomized controlled trials. PLoS ONE 2014;9(5): e95968.

5. Rudat V, Munter M, Rades D, et al. The effect of amifostine or IMRT to preserve the parotid function after radiotherapy of the head and neck region measured by quantitative salivary gland scintigraphy. Radiother Oncol 2008;89(1):71-80

6. Bagchi D, Vuchetich PJ, Bagchi M. Protective effects of zinc salts on TPA-induced hepatic and brain lipid peroxidation, glutathione depletion, DNA fragmentation, and peritoneal macrophage activation in female Swiss-Webster mice. Gen Pharmacol 1998;30(1):43-50.

7. Provinciali M, Donnini A, Argentati K, et al. Reactive oxygen species modulate $\mathrm{Zn}(2 \mathrm{t})$-induced apoptosis in cancer cells. Free Radic Biol Med. 2002;32(5):431-45

8. International Zinc Nutrition Consultative Group (IZiNCG), Brown KH, Rivera JA, et al. Assessment of the risk of zinc de ciency in populations and options for its control. Food Nutr Bull. 2004;25(1 Suppl 2):99-203.

9. Black RE, Lanata CF, Lazo F. Delayed cutaneous hypersensitivity: Epidemiologic factors affecting and usefulness in predicting diarrheal incidence in young Peruvian children. Pediatr Infect Dis J, 1989;8:210-15

10. Ertekin MV, Koc M, Karslioglu I, et al. Zinc sulfate in the prevention of radiation induced oropharyngeal mucositis: A prospective, placebo-controlled, randomized study. Int J Radiat Oncol Biol Phys 2004;58:167-74.
11. Watanabe $\mathrm{T}$, Ishihara $\mathrm{M}$, Matsuura $\mathrm{K}$, et al. Polaprezinc prevents oral mucositis associated with radiochemotherapy in patients with head and neck cancer. Int $\mathrm{J}$ Cancer 2010;127(8):1984-90

12. Najafizade N, Hemati S, Gookizade A, et al. Preventive effects of zinc sulfate on taste alterations in patients under irradiation for head and neck cancers: A randomized placebocontrolled trial. J Res Med Sci 2013;18(2):123-6.

13. Jemal A, Bray F, Center MM, et al. Global cancer statistics. CA Cancer J Clin 2011;61(2):69-90.

14. Junn JC, Sciubba JJ, Bishop JA, et al.The effect of amifostine on submandibular gland histology after radiation. Int $\mathrm{J}$ Otolaryngol 2012;2012:508279

15. Sunderman FW. The influence of zinc on apoptosis. Ann Clin Lab Sci 1995;25:134-42

16. Ertekin MV, Sezen O. In: Panglossi HV, ed. Radioprotective effects of antioxidants. Nova:Science Publisher 2007;22-39.

17. Prasad AS, Kaplan J, Beck FW, et al. Trace elements in head and neck cancer patients: Zinc status and immunologic functions. Otolaryngol Head Neck Surg 1997;116(6):624-9

18. Rostkowska-Nadolska B, Pospiech L, Bochnia M. Content of trace elements in serum of patients with carcinoma of the larynx. Arch Immunol Ther Exp (Warsz) 1999;47(5):321-5.

19. Lin LC, Que J, Lin LK, et al. Zinc suplamentation to improve mucositis and dermatitis in patients after radiotherapy head and neck cancer: a double- blind, randomized study. Int. J. Radiat Oncol Biol Phys 2006;65(3):745-50

20. Tanaka M. Secretory function of the salivary gland in patients with taste disorders or xerostomia: Correlation with zinc deficiency. Acta Otolaryngol Suppl 2002;(546):134-41.

21. Gupta T, Hotwani C, Kannan S, et al. Prospective longitudinal assessment of parotid gland function using dynamic quantitative pertechnetate scintigraphy and estimation of dose-response relationship of parotid-sparing radiotherapy in head-neck cancers. Radiat Oncol 2015;10(67):1-9. 